\title{
Neighbourhood Change and Deprivation in the Greater Manchester City-Region
}

\author{
Stephen Hincks \\ Centre for Urban Policy Studies, \\ School of Environment and Development \\ Planning and Environmental Management, \\ University of Manchester, \\ Oxford Road, \\ Manchester, \\ M13 9PL
}

Stephen.hincks@manchester.ac.uk

\section{$A$ version of this paper was published in Environment and Planning $A$}

Hincks, S. (2015) 'Neighbourhood change and deprivation in the Greater Manchester cityregion' Environment and Planning A, 47 (2), 430-449.

\begin{abstract}
There is a long lineage in neighbourhood research that has underpinned sustained academic and policy interest in the UK centred on understanding how spatial 'clusters' of neighbourhood-based deprivation might be destabilised. This has seen the privileging of composite indices in the analysis of deprivation which have been criticised for fostering a common perception that deprived neighbourhoods are homogeneous in terms of their compositions and underlying structures. Such indices have also been criticised for being ineffective at capturing temporal change, providing only static snapshots of deprivation at particular points in time. This paper focuses on patterns of deprived neighbourhood change in the Greater Manchester city-region between 2001 and 2007. It develops a typology of neighbourhood change that is triangulated with three complementary typologies capturing the socioeconomic and demographic compositions of deprived neighbourhoods; the functional roles played by deprived neighbourhoods in redistributing population through migration; and the spatial contexts in which deprived neighbourhoods are located. The analysis reveals that an overreliance on static indices to measure deprivation has longserved to conceal complexities in the way that deprived neighbourhoods change, owing to their variable structures and contexts. It illustrates the danger that lies in treating all deprived neighbourhoods in the same way.
\end{abstract}




\section{Introduction}

The long lineage in neighbourhood research, dating back to the work of the Chicago School in the 1920s, has underpinned sustained academic and policy interest in the UK. Much of this has centred on understanding how spatial 'clusters' of neighbourhood-based deprivation might be destabilised and on determining whether urban policy interventions should target people, places, or both (e.g. Fieldhouse and Tye, 1996; Rae, 2012). This focus on tackling concentrated deprivation has, since the 1970s, prompted the development of a number of composite indices designed to measure deprivation (Norman, 2010). However, deprivation indices have been criticised for fostering a common perception that deprived neighbourhoods are homogenous in terms of their compositions and underlying structures (Deas et al, 2003; Robson et al, 2008; Rae, 2009). They have also been maligned for being ineffective at capturing temporal change, providing only static snapshots of deprivation at particular points in time (see Deas et al, 2003; Norman, 2010). Admittedly, there has recently been some valuable work undertaken with regard to deprived neighbourhood change in the UK (e.g. Norman, 2010; Rae, 2012; Schultz-Baing and Wong, 2012) ${ }^{1}$.

Nevertheless, the aforementioned deficiencies have long-served to conceal the complexities underlying the way that deprived neighbourhoods change over time, owing to their variable structures and contexts.

This paper aims to demonstrate the utility of triangulating particular structural dimensions of deprived neighbourhoods with indicators measuring change over time. The analysis seeks to expose the dynamic nature of change across similarly deprived neighbourhoods and its uneven spatial patterning through time. This is achieved by focusing on three structural neighbourhood dimensions: the socioeconomic and demographic composition of neighbourhoods (Galster et al, 2003); the functional roles played by neighbourhoods in redistributing population through migration (Robson et al, 2008); and the spatial context in which a neighbourhood is located (Rae, 2009). These structural dimensions are aligned with a typology measuring relative change over time. The typology is comprised of three measures of change: claimants of job-seekers allowance (JSA), population change, and median house price change (further discussed below).

The analysis focuses on patterns of deprived neighbourhood change in the Greater Manchester city-region between 2001 and 2007. Previous studies of spatial patterns of neighbourhood change have yielded some important insights into the geography of change and have generated valuable methodological developments and policy implications as recent studies from Toronto (Hulchanksi, 2007), Chicago (Sampson, 2012), and Melbourne and London (Meen et al, 2013) underline. The adopted timeframe is also useful in that it allows us to trace change over an uninterrupted phase of economic growth whilst mirroring a period in which neighbourhood policy in England was at its height under the Labour administrations between 1997 and 2010. In structuring the analysis, three research questions are explored:

1. What are the patterns of change in claimants of job-seekers allowance, population, and house prices in Greater Manchester between 2001 and 2007?

2. How does the geography of deprived neighbourhood change relate to composition, functionality, and spatial context?

\footnotetext{
1 In 2008, the Economic Deprivation Index (EDI) was published for England. This is a deprivation index that was produced using a consistent methodology in order to track Income and Employment deprivation between 2001 and 2005. However, it was a one-off exercise that focused on a very specific neighbourhood trait.
} 
3. To what extent is the likelihood that deprived neighbourhoods will experience above average, average, or below average change in relation to its composition, functional role, and spatial context?

The next section positions the study within previous neighbourhood change research. The third section outlines the case study context and describes the methodology. The fourth section reports the results of the analysis. The final section offers a discussion of the research findings and suggests avenues for further research regarding deprived neighbourhood change.

\section{On Neighbourhood Change}

Defining neighbourhoods is crucial to the understanding of their dynamics. The early work of urban ecologists was premised on the understanding that as cities evolve through natural processes of invasion, succession, and competition, 'natural areas' emerge due to the effects of structural forces - primarily economic and social - that include industrial location and development and migration (Park, 1936). Building upon these early insights, subsequent research defined neighbourhoods according to various social (e.g. Suttles, 1972) and spatial criteria (e.g. Gould and White, 1974) including: spaces of social activity and interaction; administrative or census geographies; catchment areas for schools and doctors surgeries; and residential 'use spaces' such as parks and other local amenities (Chaskin, 1998). In addition, neighbourhoods have been defined in functional terms based on the services and institutions serving a particular area (Webster, 2003).

Whilst the conceptual underpinnings of these definitions vary, it is broadly accepted that neighbourhoods can be defined spatially and sociologically. Galster (2001: 2112) embraces this view by defining neighbourhoods as a '...bundle of spatially based attributes associated with clusters of residences, sometimes in conjunction with other land uses'. These attributes vary in terms of their geographical distribution, quality and durability, and include the likes of environmental characteristics (e.g. access to green space); proximity characteristics (e.g. location of transport nodes and infrastructure); physical attributes (e.g. building types and designs); demographic and socioeconomic characteristics (e.g. age and income); quality of local services (e.g. retail provision); political structures (e.g. political representation; investment prioritisation); and social ties (e.g. kin networks). Crucially, however, these attributes can only be measured once the geographical extent of a neighbourhood has been established (Galster, 2001).

The incremental development of theories underpinning neighbourhood change has resulted in the emergence of a variety of comprehensive models that have been used to frame analyses of change across different types of neighbourhoods (see Schwirian, 1983; Galster et al, 1987; Temkin and Rohe, 1996). These models recognise that neighbourhood change is driven by endogenous (e.g. demographic and socioeconomic characteristics; levels of deprivation and poverty; housing stock; and service provision) and exogenous factors (national policy agendas; macroeconomic performance; migration; and national housing market functioning). Galster (2001) identifies four main groups of users in a neighbourhood: households, businesses, property owners, and local government. These users consume and produce resources that help to shape changes in the neighbourhood. Accompanying interactive effects mean that changes in certain attributes in a neighbourhood will influence changes in other attributes. These will in turn affect and be affected by the decisions made by actors operating within and outside the neighbourhood itself. For prospective users of 
the neighbourhood, the outcome of these interactive effects will determine whether they choose to invest in one neighbourhood over another. For existing users, the outcome will influence whether they continue to invest in the neighbourhood or whether they choose to leave the area in response to changing neighbourhood conditions (see Kearns and Parkes, 2003).

These incremental changes will accumulate over time and will affect the internal characteristics of the neighbourhood and the way it interacts with surrounding areas (Sampson, 2012). As research has shown, deprived neighbourhoods are multi-dimensional in terms of their structures and compositions (Hincks and Robson, 2010), functionalities (Robson et al, 2008), and spatial contexts (Rae, 2009). In the immediate post-war period, social area analysis was widely used to analyse the homogeneity of neighbourhoods based on underlying compositional features or constructs (Shevky and Bell, 1955). More recently geodemographic classifications have been developed to categorise areas based on population structure and socioeconomic characteristics (Batey and Brown, 2007). Alongside these traditional analytical tools, multiple regression models have been used to predict the effects of different compositional and structural factors on the change trajectories of disadvantaged neighbourhoods (Galster et al, 2003).

Research has also shown that different types of disadvantaged neighbourhoods perform different roles in the spatial economy. Robson et al (2008) developed a typology designed to capture the different functional roles played by deprived neighbourhoods in the housing market in England. The study found that some deprived neighbourhoods act as springboards for households as they begin their housing career living in cheaper housing and subsequently moving-up the property ladder. Others attract inward moves by more affluent households in a process of improvement, and some act to trap households unable to move subsequently. Aligned to the debates regarding composition and functionality is the notion that change is affected by the spatial context within which the neighbourhood is situated (Rae, 2009). A deprived neighbourhood that is enclosed in a cluster of similarly deprived neighbourhoods will likely experience a trajectory of change that is analogous to those surrounding it (Rae, 2009; Sampson, 2012).

In keeping with these theoretical reflections, it is proposed that the analysis of deprived neighbourhood change should include the following criteria: The first is the spatial definition of deprived neighbourhood units around which to frame the analysis of change. The second is the identification of a temporal indicator or set of indicators to track change over time. The third is the adoption of analytical 'devices' to capture composition, functionality, and spatial context at the neighbourhood-level. The final criterion is the triangulation of the temporal indicators and analytical 'devices' to enable change over time to be measured in relation to structural neighbourhood dimensions. The next section outlines the case study context before these principles are operationalised in the methodology.

\section{Case Study Area}

Greater Manchester is a post-industrial city-region located in North West England, comprising ten local authority districts, with a combined population in excess of 2.5 million in 2010. Towards the end of the previous Labour administration, the Association of Greater 
Manchester Authorities (AGMA) ${ }^{2}$ submitted a proposal to central government to facilitate further decentralisation of powers and responsibilities over a range of thematic policy agendas (e.g. transport) to the city-region scale. Among other elements, this involved the strengthening of the governance architecture for the city-region around seven existing functional 'commissions' for policy themes including transport, planning, housing and economic development; and the adoption of a formal 'combined authority' for Greater Manchester (see Deas, 2013).

The city-region elites have long-been held up as pioneers of city-branding, urban entrepreneurialism, and the development of models of territorial governance that are more cohesive than in most comparable UK cities (see, Harding et al, 2010; Deas, 2013). The so called 'Manchester Miracle' - a reference to the disputed renaissance experienced by Manchester and its wider city-region over the past couple of decades - is said to have been driven by agglomerative economic growth (see MIER, 2009; Harding et al, 2010). Questions have, however, been raised over the equity of the economic transformation and the sustainability of the (Greater) Manchester experience (Deas, 2013). In addition, over the years there have been various interventions - some nationally driven through central government funded urban renewal initiatives and others 'locally' initiated - that have sought to narrow the gap between deprived and less-deprived neighbourhoods in Greater Manchester (Harding et al, 2010). However, it has been shown that the city-region is characterised by sustained levels of socio-spatial polarisation that are more marked than in any of the other principal provincial cities of England (Russell et al, 2009).

\section{Methodology}

This section outlines the methodology that was employed to analyse deprived neighbourhood change in Greater Manchester.

\section{Identifying Deprived Neighbourhoods}

This study adopts Lower Super Output Areas (LSOAs) - official census units used in England - as proxy neighbourhoods. LSOAs have an average population of 1500 people and were defined on the basis of population size, contiguity, and social homogeneity. Although the adoption of LSOAs is a methodological compromise - given the conceptual debates around neighbourhood definition explored above - LSOAs have advantages over other existing small area geographies in England: they are a fine-scale geography for which a range of demographic, social, and economic data has been released, and LSOA boundaries have remained broadly stable since their inception in 2001.

The 2004 Index of Multiple Deprivation was adopted to enable the identification of 'deprived' and 'less-deprived' neighbourhoods'. As part of the IMD methodology, each of the 32482 LSOAs in England is given a score that captures its overall performance on different core indicators. These scores are subsequently used to rank each LSOA from 1

\footnotetext{
${ }^{2}$ AGMA represents the ten local authorities of Greater Manchester. The function of AGMA is to bring together the Chief Executives and Council Leaders of each authority to coordinate responses to a range of key strategic and policy issues which impact on Greater Manchester. AGMA also provides joint services across the cityregion.

${ }^{3}$ The 2004 IMD was the first IMD produced at LSOA level and it corresponded most closely with the 2001 baseline from which neighbourhood change was measured in this study. The IMD uses a range of indicators clustered around a series of domains - income, employment, health and disability, education skills and training, barriers to housing and other services, crime and living environment - to construct a composite measure of deprivation across England.
} 
(most deprived) through to 32482 (least deprived) (Noble et al, 2006). However, because the IMD is a continuous measure of relative deprivation there is no definitive cut-off to demarcate 'deprived' from 'less-deprived' areas. In other analyses, $10 \%$ and $20 \%$ thresholds have been adopted (e.g. Robson et al, 2008; Schultz-Baing and Wong, 2012). A 20\% cut-off was used in this analysis with neighbourhoods above this threshold defined as 'deprived'. In 2004, 6496 LSOAs were above the $20 \%$ most deprived threshold in England. Of this national total, 635 were located in the Greater Manchester city-region (39\% of all LSOAs in the cityregion).

\section{Analysis of Change Indicators and the Development of a Change Typology}

The second stage involved the identification of indicators to measure change between 2001 and 2007. The indicators were assessed in relation to three criteria. First, the indicator should be consistently collected over the selected timeframe (2001-2007). Second, the data should be available at LSOA level or should be suitable for aggregation to LSOA level. Third, the indicator and the feature of change it is measuring should have a legacy of use in UK policy and/or policy evaluation at a neighbourhood level. The analysis identified three change indicators meeting these criteria that were subsequently adopted (Table 1).

Table 1: Neighbourhood Change Indicators

\begin{tabular}{|c|c|c|c|}
\hline Variable & Conceptual and Methodological Considerations & Analytical Interpretation & $\begin{array}{l}\text { Legacy in Policy or } \\
\text { Evaluation Studies }\end{array}$ \\
\hline 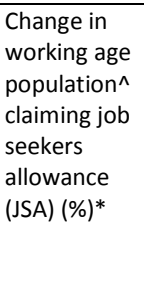 & $\begin{array}{l}\text { JSA is a commonly used measure of social distress. It has often } \\
\text { been used to capture unemployment but it has been shown } \\
\text { that JSA only records a fraction of real unemployment } \\
\text { particularly in areas of long-term unemployment (Beatty and } \\
\text { Fothergill, 2002). Nevertheless, JSA has been recorded over a } \\
\text { long period of time and at a disaggregated, neighbourhood level } \\
\text { and is a broadly acceptable compromise for capturing labour } \\
\text { market participation. }\end{array}$ & $\begin{array}{l}\text { Decline in JSA represented } \\
\text { improvement in the } \\
\text { social/economic } \\
\text { conditions of a } \\
\text { neighbourhood. An } \\
\text { increase was seen to } \\
\text { represent a worsening of } \\
\text { conditions (Hincks and } \\
\text { Robson, 2010). }\end{array}$ & $\begin{array}{l}\text { JSA was used as a key } \\
\text { performance indicator of } \\
\text { change in the evaluation } \\
\text { of the National Strategy } \\
\text { for Neighbourhood } \\
\text { Renewal (NSNR) for } \\
\text { England (DCLG, 2010). }\end{array}$ \\
\hline $\begin{array}{l}\text { Change in } \\
\text { population } \\
(\%)^{*}\end{array}$ & $\begin{array}{l}\text { A stated aim of UK government urban policy over the past } 20 \\
\text { years has been to encourage people to move back into cities. } \\
\text { Much of the regeneration effort during that time was focused } \\
\text { on redeveloping brownfield land much of it located in deprived } \\
\text { neighbourhoods. Population change was used here as a proxy } \\
\text { of changing location desirability. Ideally, change in vacancy } \\
\text { rates would have been preferable - a widely applied measure in } \\
\text { North America (see Galster et al, 2003) - but micro-scale } \\
\text { vacancy data is limited in the UK. Population change was } \\
\text { measured using the Office for National Statistics' post-censal } \\
\text { small area population estimates. These are classified as } \\
\text { experimental statistics but they have proved robust when } \\
\text { applied in similar analyses (see Schultz-Baing and Wong, 2012). }\end{array}$ & $\begin{array}{l}\text { Population growth } \\
\text { represented improvement } \\
\text { whilst a fall in population } \\
\text { was seen to be a feature of } \\
\text { neighbourhood decline } \\
\text { (Hincks and Robson, 2010). }\end{array}$ & $\begin{array}{l}\text { Population change at } \\
\text { neighbourhood level } \\
\text { featured in the National } \\
\text { Review of Housing market } \\
\text { Renewal Pathfinders } \\
\text { (2005-2007) (DCLG, 2009) }\end{array}$ \\
\hline $\begin{array}{l}\text { Change in } \\
\text { median } \\
\text { house prices } \\
(\%)^{* *}\end{array}$ & $\begin{array}{l}\text { House prices measure the relative health of the housing market. } \\
\text { House prices reflect macroeconomic circumstances, the } \\
\text { condition of the built environment, and neighbourhood } \\
\text { attractiveness among other factors (Mallach, 2008). Median } \\
\text { house prices were adopted because the median provides } \\
\text { greater stability than the mean and is less susceptible to the } \\
\text { effects of extreme values. }\end{array}$ & $\begin{array}{l}\text { An increase in house price } \\
\text { represented improvement } \\
\text { whilst a fall was seen to } \\
\text { represent decline. (Hincks } \\
\text { and Robson, 2010). }\end{array}$ & $\begin{array}{l}\text { Median house price } \\
\text { change at neighbourhood } \\
\text { level featured in the } \\
\text { National Review of } \\
\text { Housing market Renewal } \\
\text { Pathfinders (2005-2007) } \\
\text { (DCLG, 2009) }\end{array}$ \\
\hline
\end{tabular}

Source* Neighbourhood Statistics; ${ }^{* *}$ Land Registry

http://www.neighbourhood.statistics.gov.uk/dissemination/

http://www.landregistry.gov.uk/market-trend-data

Note: ^ Defined as 16-64 for males and 16-59 for females - calculated annually using post-censal small area population estimates 
Descriptive statistics were calculated for each of the indicators. Change in the population and JSA indicators was measured using the mean and so ANOVA was employed to determine whether there was a significant difference in the indicator trends between three groups of neighbourhoods in the city-region annually between 2001 and 2007. The groups were the $20 \%$ most deprived, the $20 \%$ least deprived, and the remaining neighbourhoods. Change in house prices was measured using the median and so the Kruskal-Wallis test was used in place of ANOVA. The three indicators for each year were converted into z-scores - a process that was undertaken for all neighbourhoods in the cityregion - and were subjected to sensitivity analysis using Pearson Correlation. The analysis did not reveal any problematic instances of excessive correlation. The three converted indicators were then equally weighted and subjected to linear aggregation. The aggregated indicators for all years were combined through summation to form a single variable capturing cumulative change between 2001 and 2007.

The next step involved the generation of a change typology designed to capture the direction (positive or negative) and magnitude of change taking place. The typology categorised all neighbourhoods in the city-region into one of seven types. Kitchen and Williams (2009) developed a three-fold typology - 'Improving', 'Stable', and 'Declining' - to capture the dynamics of change for neighbourhoods in Saskatoon, Canada. The categories here reflect relative change in neighbourhood performance rather than absolute change. The thresholds were defined statistically using critical z-score values for a two-tailed test:

1) Above Average $(z=\geq 1.65)$

2) Average $(z=<1.65>-1.65)$

3) Below Average $(z=\leq-1.65)$

In developing the change typology, it was necessary to make judgements as to what defined 'positive' and 'negative' change (see column 3 in Table 1). These judgements are context specific but the approach adopted here is flexible and would allow for conceptual variation.

Dimensions of Neighbourhood Change: Composition, Functionality and Spatial Context A series of typologies were used to capture composition, functionality, and spatial context. A geodemographic typology, the 2001 Office for National Statistics (ONS) Area Classification for Lower Super Output Areas (LSOAs), was used to reflect demographic and socioeconomic composition of neighbourhoods (Table 2-A). The classification included a seven-fold Super Group typology that provided a consistent basis for examining change for neighbourhoods with similar compositions (see Vickers and Rees, 2007 for details). It is important to note, however, that two of the seven categories - Countryside, and Urban Fringe - do not figure in the analysis because they do not feature any of the city-region's $20 \%$ most deprived neighbourhoods. 
Table 2: Dimensions of Neighbourhood Change Typologies

\begin{tabular}{|c|c|}
\hline \multicolumn{2}{|c|}{ A - ONS Area Typology } \\
\hline Super Group & Description of Compositional Structure \\
\hline Countryside & $\begin{array}{l}\text { This group contains neighbourhoods with a population density, a proportion of flats and public transport commuting } \\
\text { far below the national average. The variables aged 5-14, single pensioner household, one family nondependent } \\
\text { children living with parent, average household size, long-term unemployment, men working part-time, hotel and } \\
\text { catering, and health/social work are all close to the national average. The variables detached housing, working from } \\
\text { home and employment in agriculture or fishing are far above the national average. }\end{array}$ \\
\hline $\begin{array}{l}\text { Professional } \\
\text { City Life }\end{array}$ & $\begin{array}{l}\text { This group contains neighbourhoods with a proportion of the population aged 5-14, one family nondependent } \\
\text { children living with parent, detached housing, women working part time, routine and semi routine occupations and } \\
\text { employment in mining, quarrying, construction and manufacturing far below the national average. The variables } \\
\text { working from home, unemployed, long-term unemployed and men-working part time were all close to the national } \\
\text { average. The variables Indian, Pakistani, Bangladeshi, Black, not born in the UK, population density, single person } \\
\text { household (non-pensioner), private rent, flats, higher education qualifications, public transport commute and } \\
\text { students were all far above the national average }\end{array}$ \\
\hline Urban Fringe & $\begin{array}{l}\text { This group contains neighbourhoods with a proportion of public rent, terrace housing, flats, and properties with no } \\
\text { central heating far below the national average. The variables age } 5-14 \text {, aged over } 65 \text {, Indian, Pakistani, Bangladeshi, } \\
\text { not born in the UK, population density, students and health and social work are close to the national average. The } \\
\text { variable detached housing is far above the national average. }\end{array}$ \\
\hline $\begin{array}{l}\text { White Collar } \\
\text { Urban }\end{array}$ & $\begin{array}{l}\text { This group does not contain any neighbourhoods with variables that are far below or above the national average. } \\
\text { The variables aged } 0-4,5-14,25-44 \text {, over } 65 \text {, single pensioner household, terraced housing, average household size, } \\
\text { employment in agriculture and fishing, health and social work and financial intermediation are all close to the } \\
\text { national average. }\end{array}$ \\
\hline $\begin{array}{l}\text { Multicultural } \\
\text { city life }\end{array}$ & $\begin{array}{l}\text { This group contains neighbourhoods with a proportion of two adult and no children households, detached housing, } \\
\text { and households with two or more cars far below the national average. The variables work from home, routine and } \\
\text { semi routine occupations, health and social work and wholesale and retail employment are close to the national } \\
\text { average. The variables Indian, Pakistani, Bangladeshi, Black, Not born in the UK, population density, public rent, } \\
\text { flats, people per room, public transport commuting, and unemployment are far above the national average. }\end{array}$ \\
\hline $\begin{array}{l}\text { Disadvantaged } \\
\text { Urban } \\
\text { Communities }\end{array}$ & $\begin{array}{l}\text { This group contains neighbourhoods with a proportion of detached housing, higher education qualifications, and } \\
\text { households with two or more cars far below the national average. The variables aged } 25-44 \text {, aged over } 65 \text {, } \\
\text { properties with no central heating, average household size, provision of unpaid care, men and women working part } \\
\text { time are close to the national average. The variables lone parent households with dependent children, public rent, } \\
\text { limiting long term illness, and unemployment are far above the national average. }\end{array}$ \\
\hline $\begin{array}{l}\text { Miscellaneous } \\
\text { Built Up Areas }\end{array}$ & $\begin{array}{l}\text { This group does not contain any neighbourhoods with variables that are far below or above the national average. } \\
\text { The variables aged 0-4, 5-14, 25-44, Indian, Pakistani, Bangladeshi, Not born in the UK, households with two adults } \\
\text { and no dependent children, public transport commuting, provision of unpaid care, long-term unemployment, men } \\
\text { working part-time, health and social work and financial intermediation are all close to the national average. }\end{array}$ \\
\hline \multicolumn{2}{|c|}{ B - Local Indicators of Spatial Association(LISA) Typology } \\
\hline LISA Category & Description of Spatial Context \\
\hline High-High & $\begin{array}{l}\text { These neighbourhoods have a high change score and are surrounded by other neighbourhoods with similarly high } \\
\text { scores }\end{array}$ \\
\hline Low-Low & $\begin{array}{l}\text { These neighbourhoods have a low change score and are surrounded by other neighbourhoods with similarly low } \\
\text { scores }\end{array}$ \\
\hline Low-High & These neighbourhoods have a low change score but are surrounded by other neighbourhoods with high scores \\
\hline High-Low & These neighbourhoods have a change score but are surrounded by other neighbourhoods with high scores \\
\hline Variable & $\begin{array}{l}\text { For these neighbourhoods their change score and the change score of surrounding neighbourhoods are so different } \\
\text { that the relationship is statistically non-significant. }\end{array}$ \\
\hline \multicolumn{2}{|c|}{ C - Functional Neighbourhood Typology } \\
\hline Type & Description of Functional Neighbourhood Type \\
\hline Transit & $\begin{array}{l}\text { Neighbourhoods in which most in-movers come from less deprived areas and most out-movers go to less deprived } \\
\text { areas. Typically, this implies young or newly established households coming from more 'comfortable' backgrounds } \\
\text { and starting out on the housing ladder. Their early choice of housing and hence location reflects their initially limited } \\
\text { resources. For them, living in a deprived neighbourhood may entail only a short period of residence before they } \\
\text { move elsewhere to a 'better' area. }\end{array}$ \\
\hline Escalator & $\begin{array}{l}\text { These neighbourhoods have a similar role to transit areas, but in their case, since most of the in-movers come from } \\
\text { areas that are equally or more deprived, the neighbourhood becomes part of a continuous onward-and-upward } \\
\text { progression through the housing and labour markets. The moving households may be older than those in the transit } \\
\text { areas since they would not necessarily be at the start of their housing career. }\end{array}$ \\
\hline Isolate & $\begin{array}{l}\text { Neighbourhoods in which households come from and move to areas that are equally or more deprived. To this } \\
\text { degree, they are neighbourhoods that are associated with a degree of entrapment of poor households who are } \\
\text { unable to break out of living in deprived areas. }\end{array}$ \\
\hline Improver & $\begin{array}{l}\text { Neighbourhoods in which there is a degree of social improvement since most in-movers come from less deprived } \\
\text { areas. }\end{array}$ \\
\hline Variable & $\begin{array}{l}\text { These are neighbourhoods that did not meet the criteria needed for them to be included in one of the specific } \\
\text { functional categories. They have a variable role in terms of redistributing population. }\end{array}$ \\
\hline
\end{tabular}

A - adapted from Bond and Insalaco (2007); B - Anselin (2003); C - adapted from Robson et al (2008:2698) 
Spatial context was measured using the Local Indicators of Spatial Association (LISA) technique ${ }^{4}$. LISA are a suite of statistics used to decompose global spatial autocorrelation in order to measure the degree to which, in this case, a neighbourhood is similar in terms of attributes and location to those neighbourhoods surrounding it (Anselin, 2003). The attribute feature captures the nature of change (i.e. extent of change) and the locational feature reflects whether that neighbourhood was surrounded by other neighbourhoods experiencing similar or different change trajectories. The LISA technique involved three steps. First, a spatial weights matrix was calculated to determine the spatial dependence of all neighbourhoods in the city-region in relation to one another. After testing, a secondorder queen contiguity matrix was adopted. Second, the z-scores of the summed change indicator were used to calculate LISA values for each LSOA. The LISA values measure the extent to which there is a statistically significant spatial clustering of similar values around

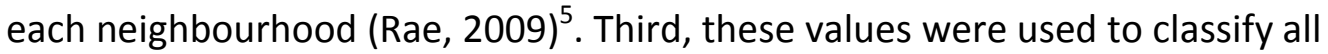
neighbourhoods in the city-region according to their attribute and locational features into one of five categories detailed in Table 2-B.

The functional roles of deprived neighbourhoods were analysed using a typology of the $20 \%$ most deprived neighbourhoods developed for England (see Robson et al, 2008). The typology was generated through an analysis of in-movers and out-movers to and from the $20 \%$ most deprived LSOAs in England defined using the 2004 IMD. The typology draws on origin-destination migration statistics from the 2001 Census and categorises LSOAs into one of four functional neighbourhood types. A fifth category is also included denoting those neighbourhoods that have a Variable functional role (Table 2-C).

Multinomial logistic regression was then employed to establish the statistical relationship between the change typology and these neighbourhood dimensions. The neighbourhood change typology was adopted as the dependent variable and the composition, functionality, and spatial context typologies were included as predicator variables. Iterative testing revealed cells with zero observations which, if left unaddressed, would impact the stability of the model. To eliminate the effects of zero observations, it was necessary to adapt the structure of certain variables. The Professional City Life and White Collar Urban neighbourhoods were excluded from the composition-based independent variable. Likewise, neighbourhoods with a Variable functional role were also excluded whilst the High-Low and Low-High categories in the spatial context independent variable were consolidated to form a single category that captured dyadic spatial context ${ }^{6}$.

Of the 635 deprived neighbourhoods in the city-region that fall into the $20 \%$ most deprived LSOAs nationally, 588 were included in the regression model. A correlation matrix was constructed to test for multicollinearity. The correlations ranged from -0.3 to 0.2 indicating that multicollinearity was limited. The regression model was built to focus on

\footnotetext{
${ }^{4}$ GeoDa was used to calculate the LISA statistics (Anselin, 2003).

${ }^{5}$ The formula used for calculating individual LISA values is:

$I_{i}=z_{i} \sum_{j}^{n} w_{i j} z_{j}$

where the observations $z_{i}, z_{j}$ are measured in deviations from the mean and the summation over $j$ only includes values of neighbouring LSOAs.

${ }^{6}$ This served to enhance the Pearson $\left(X^{2}=52.003 ; \mathrm{df}=64 ; \mathrm{p}=.858\right)$ and Deviance measures $\left(X^{2}=50.815\right.$; $\mathrm{df}=66 ; \mathrm{p}=.884)$ and reduced the standard errors in the parameters to below 1 .
} 
measuring the main effects of composition, functionality, and spatial context on the change typology.

\section{Results}

Neighbourhood Change in Greater Manchester: 2001-2007

The trends in the three untransformed individual change indicators and accompanying ANOVA results are shown in Figure 1 and Table 3, respectively. A significant difference was observed between the three groups of neighbourhoods for most years across the three change indicators. The exceptions to this are population change for the first three consecutive years of the study period and house price change in 2001-2002 and 2007-2008.

Figure 1: Trends for Untransformed Change Indicators: 2001-2007

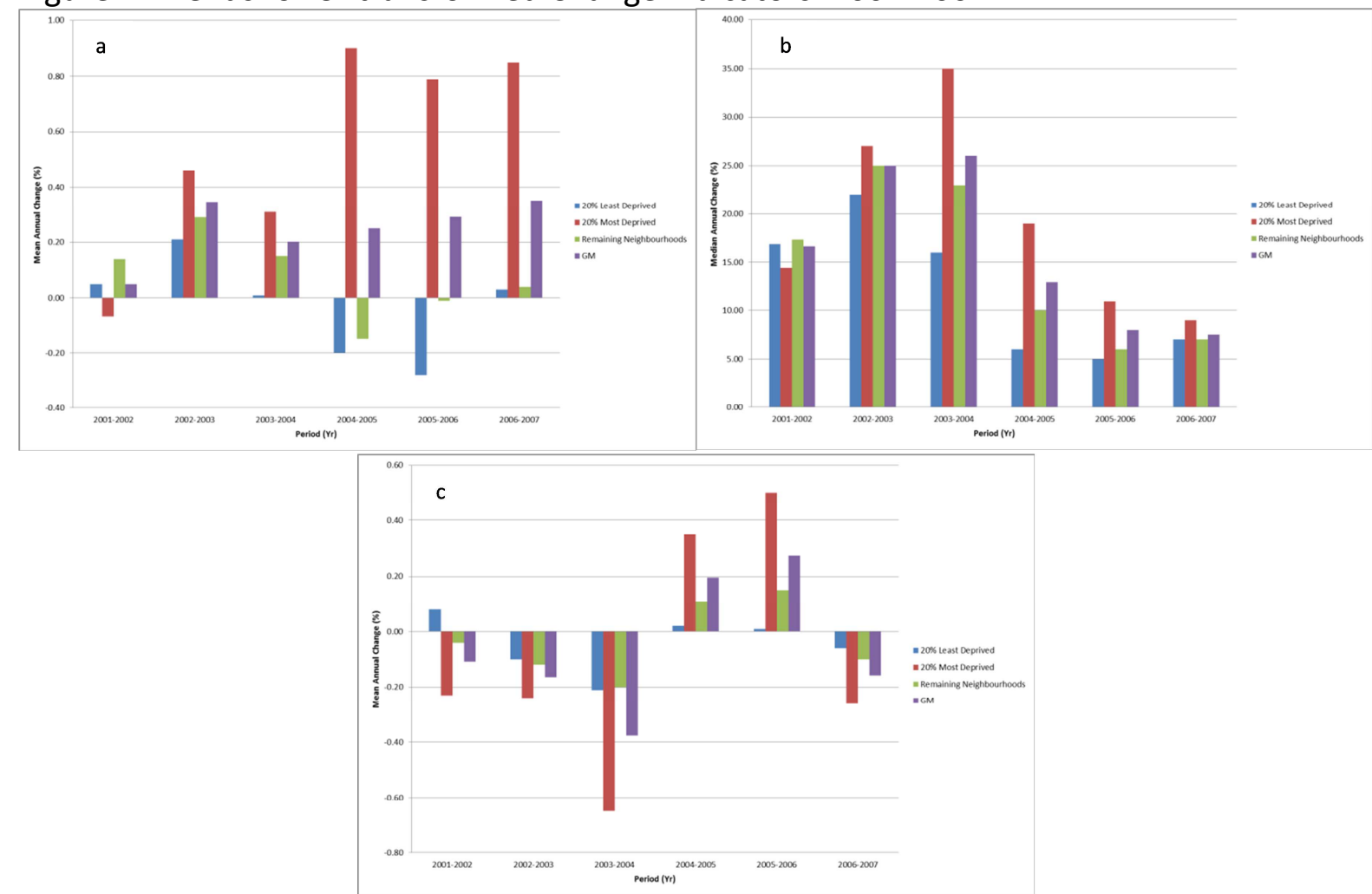

Note: a) percentage change in population; b) percentage change in median house prices; c) percentage change in working age population claiming job seekers allowance (JSA)

Between 2001 and 2007, the city-region as a whole was gaining population (a). Average change in population in the $20 \%$ most deprived neighbourhoods was at its lowest point in 2001-2002 (-0.1\%) compared to its apogee in 2004-2005 (0.9\%). In comparison, average change in the least-deprived neighbourhoods was at its highest point in 2002-2003 $(0.2 \%)$ and its lowest point in 2005-2006 (-0.3\%). Average change in the remaining neighbourhoods was at its highest in 2002-2003 (0.3\%) and its lowest point in 2004-2005 $(0.1 \%)$. Although the average annual changes in population appear relatively marginal, the analysis illustrates the presence of extensive variability across deprived and less-deprived neighbourhoods between 2001 and 2007. However, population change was most pronounced in the deprived neighbourhoods and was driven by gains made in population, 
predominantly through migration, over the study period (see Schultz-Baing and Wong, 2012).

Table 3: ANOVA Results for Change Indicators: 2001-2007

\begin{tabular}{|c|c|c|c|c|c|c|c|c|c|}
\hline \multirow[b]{2}{*}{$\begin{array}{l}\text { Period } \\
\text { (Yrs) }\end{array}$} & \multicolumn{3}{|c|}{ Population Change $^{a}$} & \multicolumn{3}{|c|}{ Median House Price Change $^{b}$} & \multicolumn{3}{|c|}{ JSA Change ${ }^{a}$} \\
\hline & Mean & Range & SD. & Median & Range & SD. & Mean & Range & SD. \\
\hline $\begin{array}{l}2001- \\
2002\end{array}$ & $\begin{array}{l}0.05 \\
\frac{0.14}{-0.07} \\
\end{array}$ & $\begin{array}{l}6.76 \\
\underline{19.78} \\
31.15 \\
\end{array}$ & $\begin{array}{l}1.22 \\
2.06 \\
2.90\end{array}$ & $\begin{array}{l}16.86 \\
17.35 \\
14.43\end{array}$ & $\begin{array}{l}123.52 \\
\underline{187.23} \\
\mathbf{3 2 6 . 1 6}\end{array}$ & $\begin{array}{l}18.57 \\
19.30 \\
32.28 \\
\end{array}$ & $\begin{array}{l}0.08^{*} \\
-0.04 \\
-0.23 \\
\end{array}$ & $\begin{array}{r}3.43 \\
4.55 \\
5.83 \\
\end{array}$ & $\begin{array}{l}0.57 \\
\underline{0.66} \\
\mathbf{0 . 9 8}\end{array}$ \\
\hline $\begin{array}{l}2002- \\
2003\end{array}$ & $\begin{array}{l}0.21 \\
0.29 \\
0.46\end{array}$ & $\begin{array}{l}8.00 \\
\underline{19.00} \\
38.00\end{array}$ & $\begin{array}{l}1.41 \\
1.90 \\
2.93\end{array}$ & $\begin{array}{l}22.00^{*} \\
\underline{25.00} \\
27.00\end{array}$ & $\begin{array}{l}100.00 \\
\underline{290.00} \\
646.00\end{array}$ & $\begin{array}{l}15.97 \\
21.45 \\
43.83\end{array}$ & $\begin{array}{l}-0.10^{*} \\
-0.12 \\
-0.24\end{array}$ & $\begin{array}{l}2.38 \\
\frac{4.13}{6.75}\end{array}$ & $\begin{array}{l}0.48 \\
0.61 \\
0.95\end{array}$ \\
\hline $\begin{array}{l}2003- \\
2004\end{array}$ & $\begin{array}{l}0.01 \\
0.15 \\
0.31\end{array}$ & $\begin{array}{l}7.00 \\
\frac{20.00}{53.00}\end{array}$ & $\begin{array}{l}1.42 \\
2.02 \\
2.85\end{array}$ & $\begin{array}{l}16.00^{*} \\
\frac{23.00}{35.00}\end{array}$ & $\begin{array}{l}93.00 \\
175.00 \\
393.00\end{array}$ & $\begin{array}{l}15.23 \\
\underline{18.75} \\
34.67 \\
\end{array}$ & $\begin{array}{l}-0.21^{*} \\
-0.20 \\
\mathbf{0 . 6 5}\end{array}$ & $\begin{array}{l}1.96 \\
\frac{5.22}{7.01}\end{array}$ & $\begin{array}{l}0.44 \\
0.61 \\
0.99\end{array}$ \\
\hline $\begin{array}{l}2004- \\
2005\end{array}$ & $\begin{array}{l}-0.20^{*} \\
\frac{-0.15}{\mathbf{0 . 9 0}}\end{array}$ & $\begin{array}{l}7.00 \\
17.00 \\
38.00 \\
\end{array}$ & $\begin{array}{l}1.32 \\
1.85 \\
2.89\end{array}$ & $\begin{array}{l}6.00^{*} \\
\underline{10.00} \\
19.00\end{array}$ & $\begin{array}{l}82.00 \\
\underline{157.00} \\
\mathbf{4 8 1 . 0 0}\end{array}$ & $\begin{array}{l}14.86 \\
\underline{16.23} \\
\mathbf{3 1 . 0 2} \\
\end{array}$ & $\begin{array}{l}0.02^{*} \\
0.11 \\
0.35\end{array}$ & $\begin{array}{l}2.36 \\
4.12 \\
7.47\end{array}$ & $\begin{array}{l}0.50 \\
0.62 \\
0.94\end{array}$ \\
\hline $\begin{array}{l}2005- \\
2006\end{array}$ & $\begin{array}{l}-0.28^{*} \\
-0.01 \\
\mathbf{0 . 7 9}\end{array}$ & $\begin{array}{l}43.00 \\
22.00 \\
43.00\end{array}$ & $\begin{array}{l}3.09 \\
2.55 \\
3.75\end{array}$ & $\begin{array}{l}5.00^{*} \\
\underline{6.00} \\
11.00\end{array}$ & $\begin{array}{l}92.00 \\
\frac{288.00}{271.00}\end{array}$ & $\begin{array}{l}15.80 \\
16.92 \\
23.76\end{array}$ & $\begin{array}{l}0.01 * \\
0.15 \\
0.50\end{array}$ & $\begin{array}{l}2.30 \\
4.57 \\
7.57\end{array}$ & $\begin{array}{l}0.47 \\
0.60 \\
1.01\end{array}$ \\
\hline $\begin{array}{l}2006- \\
2007\end{array}$ & $\begin{array}{l}0.03^{*} \\
\underline{0.04} \\
\mathbf{0 . 8 5}\end{array}$ & $\begin{array}{l}9.00 \\
\frac{22.00}{26.00}\end{array}$ & $\begin{array}{l}1.42 \\
2.02 \\
2.93\end{array}$ & $\begin{array}{l}7.00^{*} \\
\frac{7.00}{9.00}\end{array}$ & $\begin{array}{l}175.00 \\
\frac{127.00}{142.00}\end{array}$ & $\begin{array}{l}16.60 \\
12.81 \\
15.41\end{array}$ & $\begin{array}{l}-0.06^{*} \\
\frac{-0.10}{\mathbf{0 . 2 6}}\end{array}$ & $\begin{array}{l}3.22 \\
\frac{3.91}{5.78}\end{array}$ & $\begin{array}{l}0.53 \\
0.59 \\
\mathbf{0 . 8 8}\end{array}$ \\
\hline
\end{tabular}

Note: a) percentage change in population; b) percentage change in median house prices; c) percentage change in working age population claiming job seekers allowance (JSA)

(a) Measured using one-way ANOVA; (b) Measured using Kruskal-Wallis test ${ }^{*} \mathrm{p}<0.01(\mathrm{n}=1646)$

Italic - 20\% least deprived; Bold - 20\% most deprived; underlined - remaining neighbourhoods

As Figure 2(b) demonstrates, the group of deprived neighbourhoods and the two groups of less-deprived neighbourhoods all experienced sustained year-on-year growth in median house prices reflecting wider macroeconomic conditions and consumer confidence in the housing market before the financial crisis hit in 2007/08. Average change in house prices in the $20 \%$ most deprived neighbourhoods was at its highest in 2003-2004 (35\%) and was at its lowest in 2006-2007 (9\%). In comparison, average house price change in the $20 \%$ least-deprived and the remaining neighbourhood groups was recorded at its highest in 2002-2003 (22\% and 25\% respectively) and at its lowest in 2005-2006 (5\% and 6\% respectively). It is evident from these trends that both deprived and less-deprived neighbourhoods benefitted from house price inflation during the study period but that this inflation was most acute in deprived neighbourhoods. However, it is also noticeable that in 2004-2005 the scale of house price growth slowed somewhat in both deprived and lessdeprived neighbourhoods. In this period average house price change in the deprived neighbourhoods was recorded at $19 \%$. In the two less-deprived groups of neighbourhoods average change was $10 \%$ and $6 \%$ respectively. Across all groups of neighbourhoods, this represents a fall in median house price change of between $10 \%$ and $16 \%$ compared to their peaks suggesting that the housing market was responding to a shock.

This was in fact the case. In 2004-2005, the macroeconomy was in a relatively healthy condition but a dip in mortgage lending, following a fifth interest rate rise in nine months by the Bank of England, had led to speculation that the national housing market was showing signs of slow-down. House price rises levelled off - reflected in the change dynamics in Figure 2(b) - as consumer and industry confidence in the sustainability of price 
increases weakened. Nevertheless, 2001 to 2007 was a period in which the housing bubble - prior to its spectacular implosion in 2007/08 - was being fuelled by liberal and often highrisk mortgage lending and was underpinned by a national planning and development agenda that was obsessed with increasing housing supply. At this time, 'new' markets were being created in the most deprived neighbourhoods as the development sector sought to unlock the unrealised capital gains that lay in brownfield land (Schultz-Baing and Wong, 2012).

In contrast to the trends in the housing and population indicators, change in JSA (c) was somewhat more erratic during the study period, fluctuating between episodes of increase and decline. The highest decline in JSA in the $20 \%$ most deprived neighbourhoods was recorded in 2003-2004 (-0.7\%) and the highest increase was recorded in 2005-2006 (0.5\%). In comparison, the highest decline in both of the lesser-deprived neighbourhood groups was recorded in 2003-2004 (-0.2\%). The highest increase for the $20 \%$ least-deprived group and the remaining neighbourhoods was recorded in 2001-2002 (0.08\%) and 2005$2006(0.1 \%)$ respectively. Although average annual change was marginal across deprived and less-deprived neighbourhoods, the descriptive statistics are indicative of continued insecurities in the labour market, for low-skilled workers in particular, across the city-region. This insecurity is a reflection of individual circumstances. However, the most extensive change was recorded for deprived neighbourhoods suggesting that labour market insecurity was also a feature of place; specifically of deprived neighbourhoods. The remainder of the paper now turns to explore patterns of change in deprived neighbourhoods in Greater Manchester between 2001 and 2007.

\section{Patterns of Deprived Neighbourhood Change}

In focusing on change in deprived neighbourhoods, the analysis of the three-fold change typology reveals that $43 \%$ of deprived neighbourhoods performed above average; $32 \%$ performed close to the average; and $25 \%$ performed below average. The patterning of change across the $20 \%$ most deprived neighbourhoods is shown in Figure 2.

It is evident that the urban core has a high concentration of deprived neighbourhoods and many of these, located around the city centre and east Manchester, experienced change above average between 2001 and 2007 ${ }^{7}$. However, the picture is much more mixed for those neighbourhoods located in the (relative) periphery of the city-region, namely to the north, west, and east of the urban core. Deprived neighbourhoods in Greater Manchester have been targeted through decades of regeneration funding, most notably through City Challenge and the Single Regeneration Budget (SRB) in the 1990s, and New Deal for Communities (NDC), the Neighbourhood Renewal Fund (NRF), and Housing Market Renewal (HMR) during the 2000s. Between 1992 and 2008, just under $£ 1.3 \mathrm{bn}$ of central government funding was invested in Greater Manchester through these five programmes (MIER, 2009). This represents a fraction of total government and European funding that was actually invested in the city-region over the period and although these funds were not exclusively targeted towards the $20 \%$ most deprived neighbourhoods - some were restricted to the top $10 \%$ most deprived for example - it illustrates the scale of regeneration intervention seen in the city-region over the last 20 years.

\footnotetext{
${ }^{7}$ There is no official definition of the core or periphery of the city-region. However, Deas (2013) notes that the City of Manchester (Manchester Local Authority area) forms of the 'core' of the city-region - which is extended here to include the area covered by Salford City Council - with the 'periphery' including suburbs (Trafford, Tameside, and Stockport), and satellite towns (Bury, Bolton, Rochdale, and Oldham).
} 


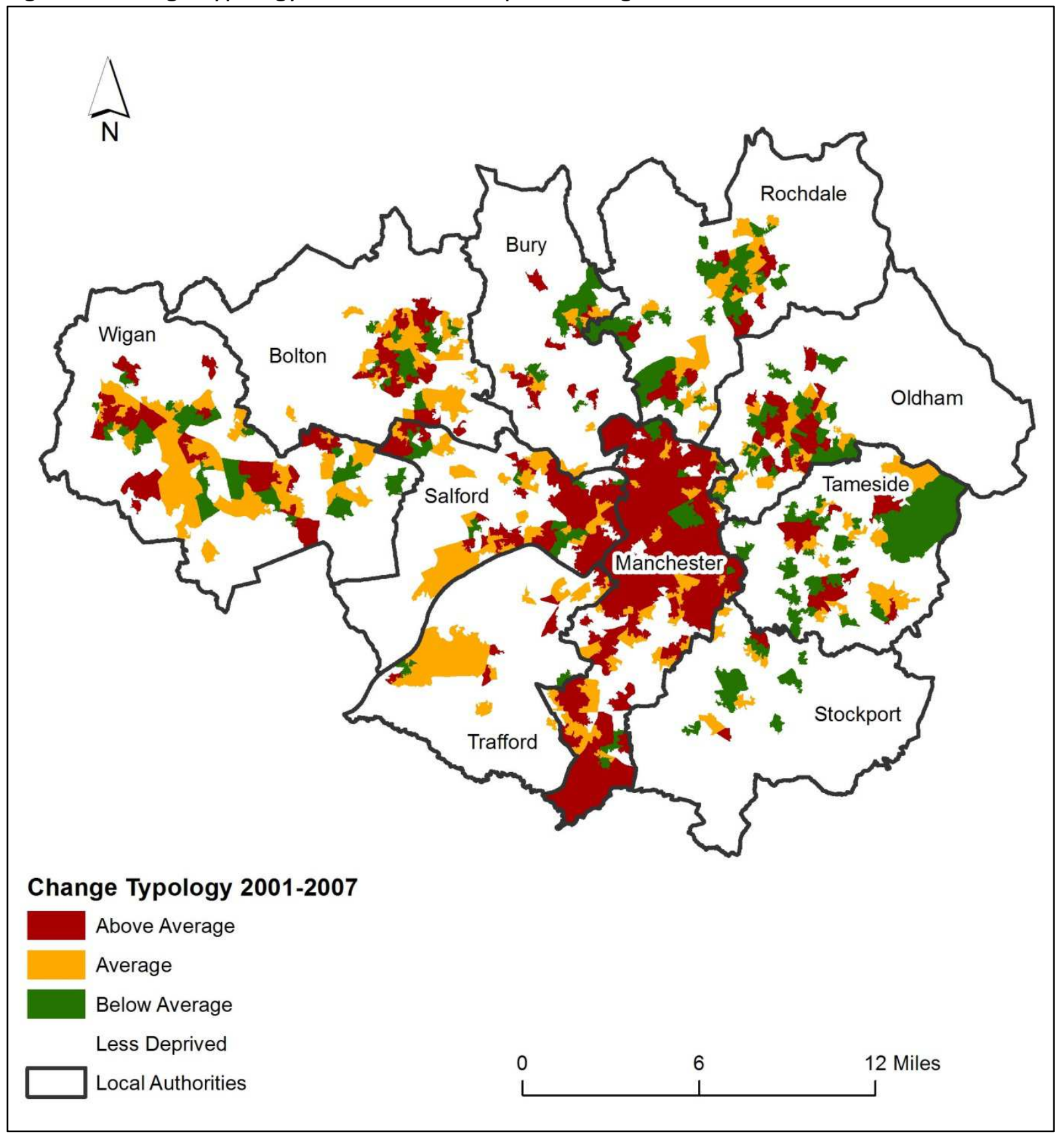

The impacts of such initiatives have been widely debated and there are conflicting perspectives as to their successes and failures. A case in point is the experience of the Housing Market Renewal Initiative. It has been argued that the programme represented a form of state-sponsored gentrification that brought government and local residents into conflict over the future of targeted neighbourhoods (Lees, 2008). Research undertaken in Greater Manchester found evidence of conflict between established and new residents moving into HMR-targeted neighbourhoods and that gentrification was a concern for residents and policymakers alike (Turcu, 2012). However, it has also been argued that HMR helped to improve the overall quality of the housing stock in targeted neighbourhoods (Turcu, 2012) and that it served to boost latent demand for rental and owner-occupied housing, predominantly in the urban core (Squires, 2009). 
Although it is not possible to establish a causal relationship between regeneration funding and outcomes through this analysis, it is notable that Manchester and Salford City Councils - the two local authorities covering the urban core of the city-region - were the beneficiaries of over half of the central government targeted funding that came through the five aforementioned regeneration programmes between 1992 and 2008 (Russell et al, 2009). The trends in the population and house price indicators and the associated patterns of change implies that deprived neighbourhoods in the urban core benefited from regeneration funding - whether directly or indirectly - and from positive externalities associated with a growing city centre-focused local economy that was well connected into a prospering national economy.

Nevertheless, the varied mosaic of change beyond the urban core suggests that more peripheral deprived neighbourhoods have not been as successful as those in the urban core at exploiting the opportunities created through agglomeration boosterism or wider regeneration efforts. This is likely to reflect the effects of both incumbent neighbourhood characteristics as well as wider structural forces that have constrained spillovers. In addition, the positive change in population and house prices in deprived neighbourhoods also masks concerning trends in labour market inactivity. An analysis of JSA reveals that $77 \%(n=493)$ of the deprived LSOAs in the city-region had a JSA claimant-rate above the Greater Manchester average in 2001 and 2007. Of these neighbourhoods, 45\% were located in the urban core and $55 \%$ in the periphery. These trends are indicative of entrenched socio-spatial polarisation and structural inequalities within and between the most deprived neighbourhoods across the city-region.

\section{Dimensions of Deprived Neighbourhood Change}

Having reflected on the broad patterns of change between 2001 and 2007, this section examines the relationship between the change typology, and the composition, functionality, and spatial context typologies using multinomial logistic regression. The distributions of the various relationships between the change typology and the neighbourhood dimensions are summarised in Figure 3.

Figure 3: Relationship between Neighbourhood Dimensions and Change Typology

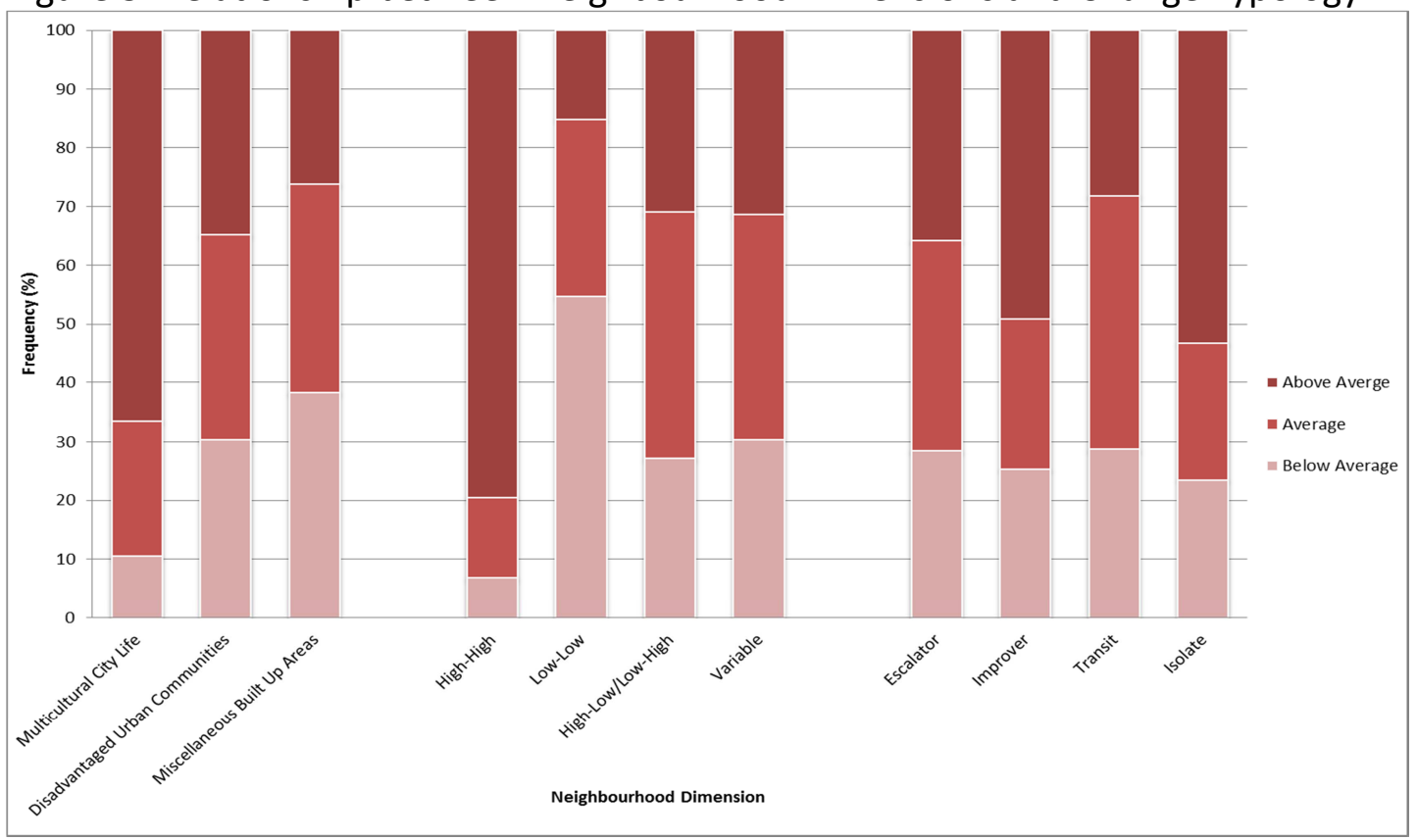


A test of the full multinomial logistic regression model against the constant only model was statistically significant with a Chi Square value of $175.259(\mathrm{df}=16)$ at $p<.000$. The overall prediction success of the model was 55\%. The -2 Log Likelihood statistics for the predictor variables composition, functionality, and spatial context were all significant $(p<.000)$ in explaining change across deprived neighbourhoods. The parameter estimates also reveal a number of significant effects of predictor variables on the dependent variable (Table 4).

Table 4: Multinomial Logistic Regression Model of Deprived Neighbourhood Change

\begin{tabular}{|c|c|c|c|c|}
\hline Variable & $\mathrm{B}$ & $\operatorname{Exp}(B)$ & Sig. & Wald \\
\hline \multicolumn{5}{|l|}{ Average Neighbourhood Group } \\
\hline Intercept & -.789 & - & 0.00 & 19.790 \\
\hline \multicolumn{5}{|l|}{ Composition } \\
\hline Multicultural City Life & -.511 & .600 & .049 & 3.799 \\
\hline Miscellaneous Built Up Areas & .434 & 1.544 & .157 & 2.004 \\
\hline Disadvantaged Urban Communities & - & - & - & - \\
\hline \multicolumn{5}{|l|}{ Functionality } \\
\hline Improver & .647 & 1.910 & 0.20 & 5.385 \\
\hline Escalator & .127 & .524 & .747 & 1.136 \\
\hline Transit & .948 & 2.576 & .001 & 12.032 \\
\hline Isolate & - & - & - & - \\
\hline \multicolumn{5}{|l|}{ Spatial Context } \\
\hline High-High & -1.692 & .184 & .000 & 33.377 \\
\hline Low-Low & .333 & 1.396 & .473 & .516 \\
\hline Low-High/High-Low & .159 & 1.172 & .657 & .198 \\
\hline Variable & - & - & - & - \\
\hline \multicolumn{5}{|l|}{ Below Average Neighbourhood Group } \\
\hline Intercept & -.493 & - & .004 & 8.426 \\
\hline \multicolumn{5}{|l|}{ Composition } \\
\hline Multicultural City Life & -1.142 & .319 & .000 & 12.509 \\
\hline Miscellaneous Built Up Areas & .703 & 2.019 & .023 & 5.143 \\
\hline Disadvantaged Urban Communities & - & - & - & - \\
\hline \multicolumn{5}{|l|}{ Functionality } \\
\hline Improver & .284 & 1.329 & .344 & .896 \\
\hline Escalator & .117 & .413 & .776 & .081 \\
\hline Transit & .277 & 1.319 & .358 & .844 \\
\hline Isolate & - & - & - & - \\
\hline \multicolumn{5}{|l|}{ Spatial Context } \\
\hline High-High & -2.094 & .123 & .000 & 31.550 \\
\hline Low-Low & 1.316 & 3.370 & .003 & 9.033 \\
\hline Low-High/High-Low & .023 & 1.023 & .954 & .003 \\
\hline Variable & - & - & - & - \\
\hline \multicolumn{5}{|c|}{$\begin{array}{l}\text {-2 log-likelihood: Composition (257.480); Functionality (246.917); Spatial Context (318.440) } \\
\text { Chi-Square: Composition (25.854; p<.000); Functionality (15.289; } p<.000) ; \text { Spatial Context (86.812; } p<.000) \\
\text { Nagelkerke'sR': .291 }\end{array}$} \\
\hline
\end{tabular}

Note: Reference category for model = Improving

In terms of the average group, only Multicultural City Life significantly affected the odds of neighbourhoods being average compared to above average with regard to composition. The odds of Multicultural City Life neighbourhoods being average performers as opposed to above average were $40 \%$ lower than for Disadvantaged Urban Communities. In relation to functionality, significant effects were identified in Improver and Transit neighbourhoods when these were compared to the reference category. Improver neighbourhoods had nearly twice the odds of being average performers than above average 
compared to Isolate neighbourhoods. This was also the case with regard to Transit neighbourhoods which had 2.5 times the odds of being average performers than above average compared to the Isolate neighbourhood group. In terms of locational context, significant effects were only identified in the High-High group when compared to the reference category. The odds of High-High neighbourhoods being average rather than above average performers were $82 \%$ lower than neighbourhoods with a Variable spatial context.

In relation to the below average group, both Multicultural City Life and Miscellaneous Built up Areas significantly affected the odds of neighbourhoods being below average performers compared to above average with regard to composition. The odds of Multicultural City Life neighbourhoods experiencing below average change rather than above average were 68\% lower than for Disadvantaged Urban Communities. In contrast, Miscellaneous Built up Areas had twice the odds of being below average than above average compared to the reference category. In terms of locational context, significant effects were identified across High-High and Low-Low categories when these were compared to the reference category. The odds of High-High neighbourhoods being below average than above average were $88 \%$ lower than for neighbourhoods with a Variable spatial context. In contrast, Low-Low neighbourhoods had nearly 3.5 times the odds of experiencing below average rather than above average performance compared to neighbourhoods with Variable spatial contexts. It was notable that none of the functional categories were statistically significant when comparing below average to above average change.

There are a number of issues raised through the regression analysis. First, the analysis demonstrates that composition, functionality and spatial context do affect the chances of a deprived neighbourhood experiencing above average, average, or below average change - albeit in distinct ways - reflecting the multi-dimensional nature of deprived neighbourhoods (Robson et al, 2008; Rae, 2009; Hincks and Robson, 2010). Second, it vividly captures the socio-spatial polarisation of similarly deprived neighbourhoods in the city-region as neighbourhoods with different underlying characteristics 'tap-into' or 'lock-into' different spatial configurations of change. Third, although neighbourhoods might ostensibly share similar compositional, functional, or contextual characteristics, the analysis reveals that neighbourhoods from the same group can also experience significantly different trajectories of change, poignantly exposing the danger of treating all deprived neighbourhoods in the same way.

\section{Discussion and Conclusion}

The argument made at the outset of this paper was that an overreliance on static indices to measure deprivation has long-served to conceal complexities in the way that deprived neighbourhoods change over time. The paper sought to demonstrate the utility of capturing both structural and change dynamics in the analysis of neighbourhood deprivation by triangulating a change typology with three complementary typologies relating to composition, functionality, and spatial context. The analysis exposed the uneven patterning of change across deprived neighbourhoods and demonstrated the danger of treating all deprived neighbourhoods in the same way.

The contribution of the paper relates to analysis that was structured around three research questions. The first part of the analysis sought to answer the question: What are the patterns of change in claimants of job-seekers allowance, population and house prices in Greater Manchester between 2001 and 2007? The ANOVA and Kruskal-Wallis test results show that, for the majority of years, change in relation to the three indicators underpinning 
the change typology was significantly different for deprived and lesser-deprived neighbourhoods. Although change was variable in deprived and less-deprived neighbourhoods both made gains in population, experienced increases in house prices, but were subject to more erratic - albeit marginal - change in JSA.

These variable experiences of change were unpacked further in relation to deprived neighbourhoods in the second stage of the analysis which sought to answer the question: how do patterns of neighbourhood change relate to composition, functionality, and spatial context? The change typology revealed that deprived neighbourhoods, particularly in the urban core, experienced sustained improvement over the period 2001 to 2007. The context here is crucial. The urban core of Greater Manchester has experienced extensive renewal efforts over the past 30 years designed to restructure the economy and to reverse a longrun decline in population of some 73\% between 1961 and 1991 (Couch, 1999). The political elite of the city of Manchester have also pursued an aggressive branding exercise to promote Manchester as a place to live, work and invest (Ward, 2000; Harding et al, 2010). This has been moulded around a broader political narrative contending that growth in the urban core will ultimately benefit the wider city-region through agglomeration externalities and spillovers (Deas, 2013; Haughton et al, 2014).

From the trends in the population and house price indicators, it would appear that growth agendas and regeneration efforts had powerful effects in reinforcing change in deprived neighbourhoods - most notably those in the urban core - by allowing targeted areas to capitalise on the potential profitability of macroeconomic conditions including housing inflation and migration. However, the politics of this process has proven to be extremely contentious at times; the experience of Housing Market Renewal is just one example of how the politics of economic boosterism has clashed with that of social justice (Turcu, 2012). In addition, unemployment and welfare dependence have remained stubbornly high across deprived neighbourhoods in Greater Manchester reflected in trends in JSA. The severity of these social problems has long been recognised by the political and policy elites operating within the Greater Manchester city-region (e.g. MIER, 2009). However, these trends suggest that agglomerative forces served-only to support positive change in those traits that were tied into a macroeconomic engine that was tending towards growth in any case - specifically housing market dynamics to which population change was intimately connected - but have been less effective at destabilising entrenched socioeconomic disparities. Yet awareness of this conflicting experience of change in neighbourhoods across (Greater) Manchester has not dampened the hyperbole about the 'Manchester Model' in national or local policy narratives (for a critical review see: Ward, 2000; Deas, 2013; Haughton et al, 2014).

Building on these insights, the third part of the analysis explored the question: To what extent is the likelihood that deprived neighbourhoods will experience above average, average, or below average change in relation to its composition, functional role, and spatial context? Overall, the analysis found a range of significant relationships between the change trajectories and neighbourhood dimensions across deprived neighbourhoods. Miscellaneous Built up Areas had higher odds of below average than above average change when compared to the reference group. In contrast, Multicultural City Life neighbourhoods had higher odds of experiencing average or below average than above average performance when compared with Disadvantaged Urban Communities. This variability points to the effects of composition on neighbourhood change (Hincks and Robson, 2010), a relationship that is likely to have been affected by various processes including migration; public and 
private sector investment; brownfield redevelopment; changing housing system dynamics alongside studentification, and gentrification, particularly in the urban core.

The analysis of functionality found that improvements in Isolate neighbourhoods outstripped those of other functional neighbourhood types. It is likely that a significant proportion of this change can be attributed to the strong macroeconomic context that amplified positive change trajectories as a result of the very low baseline position in 2001. However, Robson et al (2008) argue that Isolate neighbourhoods might perhaps be the strongest candidates for comprehensive policy intervention of any of the functional neighbourhood types. These neighbourhoods comprise households that are most likely to be trapped in poverty and vulnerable to wider macroeconomic changes compared to other functional types. During periods of economic growth, Isolate neighbourhoods will likely benefit from positive externalities - at least on the surface - but they are also likely to be the first to experience a 'reset' during difficult economic times. This potential volatility could pose significant problems for policymakers as neoliberal politics exposes such neighbourhoods to the vicissitudes of the market, leaving them periodically more vulnerable to decline compared to other functional neighbourhood types.

The analysis of the change typology in relation to the LISA classification revealed the importance of spatial context in understanding change dynamics. Perhaps as expected, High-High neighbourhoods had higher odds of undergoing above average than below average or average change, and Low-Low neighbourhoods were less likely to be performing above average than below average compared to neighbourhoods with Variable spatial contexts. Interestingly, the dyadic group did not have any significant effect on the odds of changing in any direction. It appears that the wider spatial context within which these neighbourhoods are located dampens the effects of such contextually 'atypical' change dynamics supporting the long-held contention that context matters (Sampson, 2012). Indeed, the clustering of above average or below average performing neighbourhoods could reflect the outcome of spillover effects between neighbourhoods as positive or negative change trickles across boundaries (Rae, 2009). These spillovers are likely to be reinforced by incumbent processes and socioeconomic change within neighbourhoods and the wider cluster to which the neighbourhood belongs. However, these spillovers will also be affected by structural inequalities in society and the wider spatial economy, and by the effects of state-led interventions fixed in various policy and funding regimes.

Reflecting on the analysis here it is clear that there are marked differences in the nature of change across what otherwise might be deemed, quite erroneously, a homogenous set of deprived neighbourhoods. In some ways this might appear obvious. Yet this complex mosaic of change is often overlooked in analytical and policy terms. There are avenues here that would benefit from further research. The 'portfolio' of analytical devices used in this study could be adapted, extended, or refined depending on the scope of future analyses. The analysis also made use of aggregated data meaning it was possible to track aggregate patterns of neighbourhood change. However, there was no way of tracking change at the level of the individual. This meant it was not possible to determine whether an increase in the population in a neighbourhood, for example, was because of the circulation of individuals from similarly deprived neighbourhoods or whether it was because of an influx of more affluent individuals associated with processes of gentrification. Analysis of change using individual panel-data geocoded to specific neighbourhoods or case studybased research would add further depth to the analysis here. Finally, the analysis also focused on a timeframe in which the UK national economy was growing in the period 
leading-up to the financial crash of 2007-08. Further research is now needed to explore post-recessionary experiences of deprived neighbourhoods as concerns intensify over the extent to which austerity politics is widening 'divisions' within cities (Peck, 2012). Although the analysis has focused on the Greater Manchester city-region, it is hoped that the findings will stimulate further critical debate around understanding change across disadvantaged neighbourhoods in the UK and elsewhere.

\section{References}

Anselin, L. (2003) GeoDa 0.9 User's Guide. Center for Spatially Integrated Social Science, Urbana-Champagne.

Batey, P. and Brown, P. (2007) 'The spatial targeting of urban policy initiatives: a geodemographic assessment tool' Environment and Planning A, 39, 2774-2793.

Beatty, C. and Fothergill, S. (2002) 'Hidden unemployment among men: a case study' Regional Studies, 36, 811-823.

Bond, S. and Insalaco, F. (2007) 'Area Classification of Super Output Areas and Datazones'. Final Report. London, ONS.

Chaskin, R. (1998) 'Neighbourhood as a Unit of Planning and Action: A Heuristic Approach' Journal of Planning Literature, 13 (11), 11-30.

Couch, C. (1999) 'Housing Development in the City Centre' Planning Practice and Research, 14 (1), 69-86.

Deas, I. (2013) 'The search for territorial fixes in subnational governance: city-regions and the disputed emergence of post-political consensus in Manchester, England' Urban Studies, DOI: $10.1177 / 0042098013510956$.

Deas, I., Robson, B., Wong, C. and Bradford, M. (2003) 'Measuring neighbourhood deprivation: a critique of the Index of Multiple Deprivation' Environment and Planning $C, 21$, 883-903.

Department for Communities and Local Government (DCLG) (2009) National Evaluation of Housing Market Renewal Pathfinders 2005-2007. London, HMSO.

DCLG (2010) Evaluation of the National Strategy for Neighbourhood Renewal: Final Report. London, HMSO.

Fieldhouse, E.A. and Tye, R. (1996) 'Deprived people or deprived places? Exploring the ecological fallacy in studies of deprivation with the Samples of Anonymised Records' Environment and Planning A, 28 (2), 237-259.

Galster, G. (2001) 'On the nature of neighbourhood' Urban Studies, 38, 2111-2124. Galster, G.C., Quercia, R.G., Cortes, A. And Malega, R. (2003) 'The Fortunes of Poor Neighbourhoods' Urban Affairs Review, 39 (2), 205-226.

Galster, G., Cutsinger, J. and Lim, U. (2007) 'Are Neighbourhoods Self-stabilising? Exploring Endogenous Dynamics' Urban Studies, 44 (1), 167-185.

Gould, P. and White, R. (1974) Mental Maps. Middlesex, UK, Penguin.

Grigsby, W., Baratz, M., Galster, G. and Maclennan, D. (1987) 'The Dynamics of Neighbourhood Change and Decline' Progress in Planning, 28, 1-76.

Harding, A., Harloe, M. and Rees, J. (2010) 'Manchester's Bust Regime' International Journal of Urban and Regional Research, 34 (4), 981-991.

Haughton, G., Deas, I. and Hincks, S. (2014) 'Making an impact: when agglomeration boosterism meets antiplanning rhetoric' Environment and Planning A, 46 (2), 265-270. Hincks, S. and Robson, B. (2010) Regenerating Communities First Neighbourhoods in Wales. York, JRF. 
Hulchanski, D.J. (2007) The Three Cities Within Toronto. Toronto, University of Toronto. Kearns, A. and Parkes, A. (2003) 'Living in and leaving poor neighbourhood conditions in England' Housing Studies, 18, 827-840.

Kitchen, P. and Williams, A. (2009) 'Measuring Neighbourhood Social Change in Saskatoon, Canada: A Geographic Analysis' Urban Geography, 30 (3), 261-288.

Lees, L. (2008) 'Gentrification and Social Mixing: Towards an Inclusive Urban Renaissance? Urban Studies, 45 (12), 2449-2470.

Mallach, A. (2008) Managing Neighbourhood Change: A Framework for Sustainable and Equitable Revitalization. New Jersey, National Housing Institute.

Manchester Independent Economic Review (MIER) (2009) Reviewer's Report. Manchester, MIER.

Meen, G., Nygard, C., and Meen, J. (2013) 'The causes of long-term neighbourhood change'. In van Ham, M. Manley, D. Bailey, N. Simpson, L. and Maclennan, D. (Eds.) Understanding neighbourhood dynamics: New insights for neighbourhood effects research. Springer, London, pp. 46-62.

Noble, M. Wright, G. Smith, G. and Dibben, C. (2006) 'Measuring multiple deprivation at the small-area level' Environment and Planning A, 38, 169-185.

Norman, P. (2010) 'Identifying change over time in small area socio-economic deprivation' Applied Spatial Analysis and Policy, 3, 107-138.

Park, R.E. (1936) 'Human Ecology' American Journal of Sociology, XLII, 1-15.

Peck, J. (2012) 'Austerity Urbanism' City, 16 (6), 626-655.

Rae, A. (2009) 'Isolated Entities or Integrated Neighbourhoods? An Alternative View of the Measurement of Deprivation' Urban Studies, 46(9), 1859-1878.

Rae, A. (2012) 'Spatially Concentrated Deprivation in England: An Empirical Assessment' Regional Studies, 46 (9), 1183-1199.

Robson, B., Lymperopoulou, K. and Rae, A. (2008) 'People on the move: exploring the functional roles of deprived neighbourhoods' Environment and Planning A, 40(11), 2693-

2714.

Russell, G., Stowe, P., Twomey, J. and Robson, B. (2009) Sustainable Communities:

Manchester Independent Economic Review. Manchester, MIER.

Sampson, R.J. (2012) Greater American City: Chicago and the Enduring Neighbourhood Effect. Chicago, Chicago University Press.

Schultz Baing, A. and Wong, C. (2012) 'Brownfield Residential Development: What Happens to the Most Deprived Neighbourhoods in England?' Urban Studies, 49 (14), 2989-3008.

Schwirian, K.P. (1983) 'Models of Neighbourhood Change' Annual Review of Sociology, 9, 83102.

Shevky, E. and Bell, W. (1955) Social Area Analysis. Stanford, Stanford University Press. Squires, G. (2009) 'The Regeneration of Low Demand Neighbourhoods: The Housing Market Renewal Experience' Unpublished PhD Thesis. Manchester, University of Manchester.

Suttles, G.D. (1972) The Social Construction of Communities. Chicago, University of Chicago Press.

Temkin, K. and Rohe, W. (1996) 'Neighbourhood Change and Urban Policy' Journal of Planning Education and Research, 15, 159-170.

Turcu, C. (2012) 'Local experiences of urban sustainability: Researching Housing Market Renewal interventions in three English neighbourhoods' Progress in Planning, 78 (3), 101150. 
Vickers, D, and Rees, P. (2007) 'Creating the National Statistics 2001 Output Area Classification' Journal of the Royal Statistical Society, Series A, 170 (Part 2), 379-403.

Ward, K. (2000) 'Front Rentiers to Rantiers: 'Active Entrepreneurs', 'Structural Speculators' and the Politics of Marketing the City' Urban Studies, 37 (7), 1093-1107.

Webster, C. 'The Nature of the Neighbourhood' Urban Studies, 40 (13), 2591-2612.

\section{Acknowledgements}

Thank you to lain Deas and Anna Gilchrist, University of Manchester, for comments on an earlier draft of this paper. Thanks also to the three anonymous referees whose comments have improved substantially the scope and quality of the paper. Finally, thanks to the Editor and the editorial team for their patience during the drafting of this paper. The usual disclaimers apply. 